\title{
Magnetized Water Confers Drought Stress Tolerance in Moringa Biotype via Modulation of Growth, Gas Exchange, Lipid Peroxidation and Antioxidant Activity
}

\author{
Md. Mahadi Hasan", 2*, Hesham F. Alharby ${ }^{2}$, Md. Nashir Uddin ${ }^{5}$, Md. Arfan Ali ${ }^{3,4}$ \\ Yasir Anwar ${ }^{2}$, Xiang-Wen Fang ${ }^{1 * *}$, Khalid Rehman Hakeem², Yahya Alzahrani², \\ Abdulrahaman S. Hajar ${ }^{2}$ \\ ${ }^{1}$ State Key Laboratory of Grassland Agro-Ecosystems, School of Life Sciences, Lanzhou University, \\ Lanzhou, Gansu Province, China \\ ${ }^{2}$ Department of Biological Sciences, Faculty of Science, King Abdulaziz University, Jeddah, Saudi Arabia \\ ${ }^{3}$ Department of Arid Land Agriculture, Faculty of Meteorology, Environment and Arid Land Agriculture, \\ King Abdulaziz University, Jeddah, Saudi Arabia \\ ${ }^{4}$ Department of Horticulture, Faculty of Agriculture, Sher-e-Bangla Agricultural University, Dhaka, Bangladesh \\ ${ }^{5}$ Department of Biochemistry and Microbiology, School of Health and Life Sciences, \\ North South University, Dhaka, Bangladesh
}

Received: 16 April 2019

Accepted: 27 June 2019

\begin{abstract}
The present study assesses the effect of drought stress on the Moringa biotype under magnetized water treatment (MWT). The Moringa biotype seedlings were subjected to drought stress with varying field capacities (FC) viz., control (100\% FC), moderate drought stress (MS,50\% FC), and severe drought stress (SS, 20\% FC). Magnetized water (MW) significantly increased plant height, leaflet number, internode distances, leaf area, dry weight of the leaf, shoot, root of the seedlings and markedly improved the assimilation, transpiration, stomatal conductance, water use efficiency and vapor pressure deficit under drought stress conditions. The maximum quantum efficiency of PSII (Fv/Fm) and maximum chlorophyll fluorescence $(\mathrm{Fm})$ were increased and minimum chlorophyll fluorescence $\left(\mathrm{F}_{0}\right)$ in the darkadapted state was decreased under drought stress with MWT. Photosynthetic pigments (Chl a, Chl b, carotenoids) significantly decreased under drought stress, but MW significantly increased them. The MW application in Moringa biotype resulted in a decrease in total phenolic content (TPC) by $19 \%$ and $26 \%$ under MS and SS conditions, respectively. Malondialdehyde(MDA), hydrogen peroxide $\left(\mathrm{H}_{2} \mathrm{O}_{2}\right)$ and accumulation of proline in leaf were decreased with the prolongation of drought with MW. MW could be
\end{abstract}

*e-mail: hasanmahadikau@gmail.com

**e-mail: fangxw@1zu.edu.cn 
used for alleviating the drought stress in Moringa biotype seedlings and improve drought tolerance by modulating the physiological activities.

Keywords: magnetized water, malondialdehyde, hydrogen peroxide, phenolic compounds, maximum quantum efficiency of PSII

\section{Introduction}

Increasing greenhouse gas emissions have caused huge changes in climatic conditions and this phenomenon has led to increased global temperatures [1]. There are two key natural features, viz., drought and high temperature stresses, that can remarkably affect crop productivity [2]. Due to rising temperature and shortage of rainfall, most of the cultivated land becomes dry land or desert and it rapidly changes into semi-arid and arid areas [3-4]. A shortage of water hinders the development and potency of the plants, which results in low crop production [5-7]. Drought stress is one of the detrimental abiotic stresses affecting the leaf, shoot, root growth and development as well as depleting plant maturation $[8,9]$.

Drought stress has been mitigated by using different approaches, including the exogenous application of various chemical and biological agents as well as incorporating various physical methods. Research suggests that various chemical compounds, including proline, abscisic acid (ABA), salicylic acid, jasmonic acid, betain and spermidine, amino acid, hydrogen peroxide $\left(\mathrm{H}_{2} \mathrm{O}_{2}\right)$, humic acid, nitric acid and antioxidants have been proven to be useful agents to mitigate drought stress [10-13]. In addition to these exogenous supplies of biochemical agents, recently the latest strategies and techniques - including robotics, GIS technology, sensors and magnetic water technology - were used as beneficial tools in order to alleviate drought stress among crop plants [14].

Magnetic water technology is regarded as one of the most eco-friendly and effective tools in modern agriculture practices. Magnetized water (MW) is usually generated by treating the normal irrigation water by magnetic field [15]. Studies have reported that magnetic water treatment changes water quality, including its molecular and other properties [16]. These changes occur due to changes in the nuclei of water molecules [16-19] and the increasing number of centers of crystallization and free gas amount [20], which in turn improves water quality. For example, MW exhibits weakened hydrogen bonds, reduced polymerization and improved water solubility as compared to pure water [21]. MW for irrigation can promote water productivity and nutrients by plants [2223]. Recently, the potential of MW has been studied in order to increase germination, seedling growth and development - particularly when plants are under various abiotic stresses [21, 24]. Liu et al. (2019) [21] found that irrigating Populus seedlings with MW could reduce salt stress.
Moringa sp. belonging to the family Moringaceae is an important source of food and medicine [14]. In our previous studies, Moringa oleifera and Moringa peregrina have shown great potential during drought conditions when treated with MW [14, 25]. The Moringa biotype was used in this study, which have both Moringa oleifera and Moringa peregrina characteristics, and it was found in the Al Bahah Region of Saudi Arabia [26-27]. The studied Moringa biotype has leaflets round, oblanceolate or elliptical, which are analogous to leaflets of $M$. oleifera and $M$. peregrina [27]. The morphological and genetic studies of the Moringa biotype have been reported previously [26-27], but physiological and biochemical studies of this Moringa biotype under drought stresses are absent. Therefore, in the current study, we have investigated the effects of MW on this Moringa biotype under different levels of drought stress. We have compared the effects of magnetized water with the control (Normal irrigated tap water) on the morphological characteristics, including growth and various physiological as well as biochemical parameters, including leaf gas exchange, chlorophyll content, phenolic compounds and antioxidant capacity of Moringa biotype seedlings during drought stress conditions. Studying the biochemical and physiological markers of drought tolerance of this Moringa biotype could further help us in understanding the effect of MW in alleviating drought stress in plants.

\section{Materials and Methods}

\section{Plant Material and Experimental Design}

Seeds of the Moringa biotype were collected from the Al Bahah region $\left(18.22^{\circ}\right.$ and $\left.42.51^{\circ}\right)$ in Saudi Arabia, as described by Robiansyahet et al. (2015) [26]. The experiment was carried out in a $9 \mathrm{~m}$ long and $4 \mathrm{~m}$ wide greenhouse located at KAU, Jeddah, Saudi Arabia and sandy loam soil mixed with peat moss and compost (1:1:1) was used during the experiment. The seeds of the Moringa biotype were sown on the same day in the pots and arranged in randomized completely block design (RCBD) with three replications. Plants were cultivated in the greenhouse with a day:night mean temperature of $25: 20^{\circ} \mathrm{C}$ and a $16 \mathrm{~h}$ day $/ 8 \mathrm{~h}$ night photoperiod. The relative humidity was $50-70 \%$.

\section{Drought Stress Treatments}

Sixty-day-old plants were subjected to drought treatments including $100 \% \mathrm{FC}, 50 \% \mathrm{FC}$, and $20 \% \mathrm{FC}$, 
and the FC was maintained by weighing the pot every day. The leaf samples were collected during harvest time.

\section{Magnetic Treatments}

The water was treated with a magnetic device by following the methods of Selim and El-Nady (2011) and Liu et al al. (2019) [21, 28]. A magnetic treatment device was used for treating water with a permanent magnet (U050 mg, 0.5 in., output 4-6 m3 $\mathrm{h}^{-1}$ ) and a magnetic induction of approximately $300 \mathrm{Gs}$, produced by Magnetic Technologies L.C.C. (Russia, United Arab Emirates branch). The potted seedlings were irrigated with drought treatments in the presence or absence of magnetic treatment. The pots were arranged into six experimental groups:

i. (Control $+\mathrm{NW})$ : the plants were grown with normal water treatment with $100 \%$ FC.

ii. (Control $+\mathrm{MW})$ : the plants were grown with magnetic water treatment with $100 \%$ FC.

iii. $(\mathrm{MS}+\mathrm{NW})$ : the plants were cultivated with normal water treatment that was subjected to moderate drought stress(MS, 50\% FC).

iv. (MS+MW): the plants were cultivated with magnetic water treatment that was subjected to moderate drought stress (MS, 50\% FC).

v. $(\mathrm{SS}+\mathrm{NW})$ : the plants were cultivated with normal water treatment that was subjected to severe drought stress (SS, 20\% FC).

vi. SS+MW): the plants were cultivated with magnetic water treatment that was subjected to severe drought stress (SS, 20\% FC).

\section{Growth Conditions}

Four growth-related parameters such as plant height, leaf number, leaflet number, and internode distances were measured at one-week intervals until harvest. Harvesting was done by cutting plants from the soil surface and the fresh weight was determined after the separation of stems and leaves. Two leaves of each plant were collected and put into sealed vials, frozen in liquid $\mathrm{N}_{2}$ and stored in a freezer $\left(-80^{\circ} \mathrm{C}\right)$. Roots were cleaned by removing the soil through gentle washing by tap water and then dried using thick tissue. The same root was weighed and put into a paper bag and oven-dried at $65^{\circ} \mathrm{C}$ for $72 \mathrm{~h}$ to measure the dry weight.

\section{Leaf Area (LA) and Relative Water Content (RWC)}

LA of Moringa biotype was measured by a leaf area meter supplied by LICOR-3000A, USA. Fresh weight (FW) of the leaf samples were collected followed by keeping the leaf disc in a petri dish in deionized water for $8 \mathrm{~h}$ in the dark to calculate the RWC. Turgid weight (TW) was measured after removing excess water in the surface and the dry weight data were collected after oven drying the samples for 48 hours at $80^{\circ} \mathrm{C}$.

To calculate RWC, the following formula was used:

Relative water content, RWC (\%) $=\frac{\text { FW }- \text { DW }}{\text { TW }- \text { DW }} \times 100$

\section{Leaf Gas Exchange}

Assimilation rate $\left(\mathrm{A}, \mathrm{CO}_{2} \mathrm{~m}^{-2} \mathrm{~s}^{-1}\right)$ stomatal conductance (gs, mol $\mathrm{CO}_{2} \mathrm{~m}^{-1} \mathrm{~s}^{-1}$ ), transpiration rate (E, $\mathrm{mmol} \mathrm{CO}_{2} \mathrm{~m}^{-2} \mathrm{~s}^{-1}$ ), vapor pressure deficit (VPD, $\mathrm{kPa}$ ) and water use efficiency (WUE, $\mu \mathrm{molCO}_{2} \mathrm{mmol}^{-1} \mathrm{H}_{2} \mathrm{O}$ ) were measured as leaf gas exchange parameters using a CIRAS III photosynthesis system. The young and healthy leaf samples were taken into consideration for measurement and the data were collected in-between 12:00 and 14:00h in the afternoon. An average of three randomly selected leaves data were considered for analysis.

\section{$\mathrm{Fv} / \mathrm{Fm}$}

Fv/Fm was collected at an interval basis on the same leaves used for gas exchange measurements. All the leaf samples were measured after dark adaption for 30 mins with leaf cuvette using a CIRAS III photosynthesis system.

\section{Photosynthetic Pigments}

Photosynthetic pigments were extracted following the method explained by Lichtenthaler and Wellburn (1983) [29]. Mortar and pestle were used to crush $0.5 \mathrm{~g}$ homogenized leaf samples and $10 \mathrm{ml}$ of acetone $(80 \% \mathrm{v} / \mathrm{v})$ added, followed by centrifuging at $5,000 \times \mathrm{g}$ for 10 min. A UV-visible spectrophotometer (UV-1900) was used to find the absorbance of 663,645 and $470 \mathrm{~nm}$ respectively.

\section{Determining Ion Content}

One $\mathrm{ml}$ of sulphuric acid $\left(\mathrm{H}_{2} \mathrm{~S}_{4}\right)$ was added to each digestion tube containing plant sample (powder form) and then transfer to the sand heater. Completion of digestion takes 15-20 min by changing into dark color. After cooling the samples, $1 \mathrm{ml}$ mixture of $\mathrm{H}_{2} \mathrm{SO}_{4}$ and percloric acid $\left(\mathrm{HCLO}_{4}\right.$ in equal ratio) was added and heated for 30-40 min again until the transparent color appeared. Then $100 \mathrm{ml}$ distilled water was added to each sample tube. Optima ICP-OECS machine was used to determine the ion contents such as $\mathrm{Na}^{+}, \mathrm{K}^{+}, \mathrm{Ca}^{2+}$, $\mathrm{Mg}^{2+}, \mathrm{Cu}^{2+}, \mathrm{Fe}^{2+}, \mathrm{Mn}^{2+}, \mathrm{P}^{5+}$, and $\mathrm{Ni}^{2+}$. This method was described by Humpherics (1956) [30].

\section{Methanolic Extract Preparation}

Methanolic extract was prepared by centrifuging $2.0 \mathrm{~g}$ of leaves of Moringa biotype $150 \mathrm{rpm}$ along with 
$20 \mathrm{ml}$ methanol $(80 \%)$ for $12 \mathrm{~h}$, followed by filtration by filter paper.

\section{Estimating Total Phenolic Content (TPC)}

TPC was measured following the procedures explained by Velioglu et al. (1998) [31]. $50 \mu \mathrm{L}$ of methanolic extract was mixed with Folin-Ciocalteu reagent $(100 \mu)$ and methanol $(850 \mu)$. The mixture was kept for $5 \mathrm{~min}$ at ambient condition. $500 \mu \mathrm{l}$ of $20 \% \mathrm{NaCO}_{3}$ was added again to this mixture and we allowed the reaction to occur for another 30 mins. OD was measured at $750 \mathrm{~nm}$ and TPC was quantified using a calibration curve that was made by measuring the absorbance of known concentrations of gallic acid. Gallic acid equivalent/g tissues were used to express the results.

\section{Estimating Total Flavonoid Content (TFC)}

TFC was determined by using a modified colorimetric method described by Zhishen et al. (1999) [32]. $250 \mu \mathrm{L}$ of $\mathrm{ME}$ (standard solution) was mixed with $1.25 \mathrm{ml}$ distilled water and $75 \mu \mathrm{L}$ of $5 \%$ sodium nitrite solution and kept for $6 \mathrm{~min}$ for reaction. $150 \mu \mathrm{L}$ of $10 \% \mathrm{AlCl}_{3}, 0.5 \mathrm{ml}$ of $1 \mathrm{M} \mathrm{NaOH}$ and $275 \mu \mathrm{L}$ distilled water were also added to the mixture after 5 mins. Flavonoids were quantified using a calibration curve obtained by measuring the OD of catechin of known concentrations, and absorbance was calculated at $510 \mathrm{~nm}$. The results were expressed as milligram (mg) of catechin equivalent/g tissues.

\section{Proline Assay}

Free proline content was measured following the procedures described by Bates et al. (1973) [33] with minor modifications. Fresh leaf tissues $(0.5 \mathrm{~g})$ were taken and homogenized in $10 \mathrm{~mL}$ of $3 \%$ sulfosalicylic acid in ice. The sample was centrifuged for $15 \mathrm{~min}$ at $11,500 \times \mathrm{g}$ followed by a collection of $2 \mathrm{~mL}$ of the filtrate. Then $2 \mathrm{~mL}$ acid ninhydrin and $2 \mathrm{~mL}$ glacial acetic acid was added to the extract and allowed for reaction. The mixture was incubated at $100^{\circ} \mathrm{C}$ for an hour. After cooling the mixture, $4 \mathrm{~mL}$ of toluene was added. The absorbance was taken at $520 \mathrm{~nm}$. From the standard curve, the amount of proline was determined and expressed as $\mu \mathrm{g} / \mathrm{g}$ FW.

\section{DPPH Radical Scavenging Assay}

Free radical scavenging activity of methanol extract (ME, equivalent to 20,40 , and $60 \mu \mathrm{l}$ ) was determined by using 1-diphenyl-2-picrylhydrazyl (DPPH) described by Ao et al. (2008) [34]. $0.1 \mathrm{ml} \mathrm{ME} \mathrm{was} \mathrm{added} \mathrm{to}$ $0.9 \mathrm{ml}$ newly prepared $0.1 \mathrm{mM}$ of DPPH methanol solution. The same amount of methanol was used as control. The reacted mixture was incubated for half an hour in a dark room under normal temperatures. The OD was measured at $517 \mathrm{~nm}$ and the following formula was used to calculate the radical scavenging activity $(\%)$ :

DPPH radical scavenging $(\%)=\frac{(\text { OD Control }- \text { OD Sample })}{\text { OD Sample }} \mathrm{X} 100$

\section{Measurement of Lipid Peroxidation}

Malondialdehyde (MDA) concentrations act as an indicator for the level of lipid peroxidation and measurement was done by following the methods described by Heath and Packer (1968) [35]. Thiobarbituric acid (TBA) was used as the reactive material for measuring the MDA. $0.5 \mathrm{~g}$ leaf samples were homogenized in $3 \mathrm{~mL} 5 \%(\mathrm{w} / \mathrm{v})$ trichloroacetic acid (TCA). The homogenate was allowed for centrifugation at $11,500 \times \mathrm{g}$ for $10 \mathrm{~min}$. $1 \mathrm{~mL}$ supernatant was collected and mixed with $4 \mathrm{~mL}$ TBA reagent, which consisted of $0.5 \%$ TBA dissolved in $20 \%$ TCA. A hot
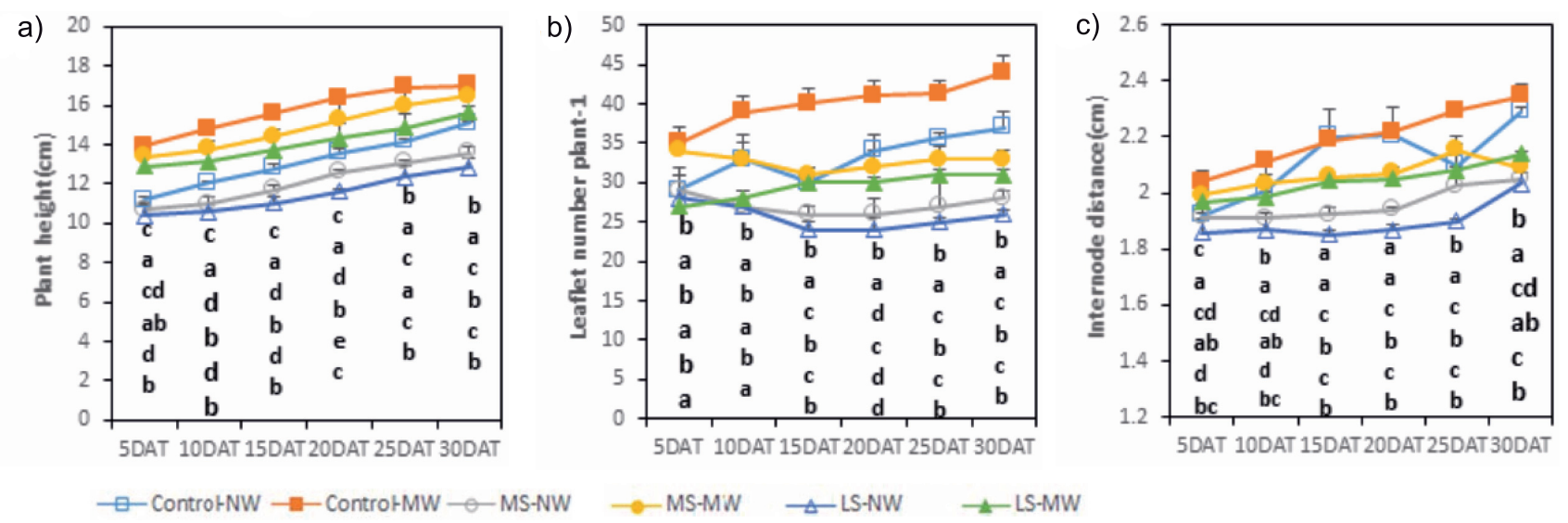

Fig. 1. Effect of magnetized water (MW) on plant height a), internode distances c), and leaflet number b) of the Moringa biotype seedlings under drought stress at 5DAT to 30DAT (days after treatment); vertical bar represents the standard deviation and different letters below the series denote statistically significant $(\mathrm{P} \leq 0.05)$ differences among treatments. 
Table 1. Interaction effect between Moringa biotype vs. water on fresh weight (FW) and dry weight (DW) of root, stem, leaf, and root number.

\begin{tabular}{|c|c|c|c|c|c|c|}
\hline \multirow{2}{*}{ Treatments } & \multicolumn{2}{|c|}{ Root } & \multicolumn{2}{c|}{ Shoot } & \multicolumn{2}{c|}{ Leaf } \\
\cline { 2 - 7 } & FW & DW & FW & DW & FW & DW \\
\hline Control+ NW & $18.4 \pm 1 \mathrm{ab}$ & $3.2 \pm 0.1 \mathrm{ab}$ & $1.63 \pm 0.3 \mathrm{bc}$ & $0.44 \pm 0.03 \mathrm{~b}$ & $6.8 \pm 0.7 \mathrm{bc}$ & $1.7 \pm 0.08 \mathrm{~b}$ \\
\hline Control+ MW & $19.2 \pm 1.75 \mathrm{a}$ & $3.3 \pm 0.17 \mathrm{a}$ & $2.16 \pm 0.2 \mathrm{a}$ & $0.54 \pm 0.05 \mathrm{a}$ & $8.1 \pm 0.7 \mathrm{a}$ & $2.06 \pm 0.25 \mathrm{a}$ \\
\hline MS+NW & $17.2 \pm 0.45 \mathrm{bc}$ & $3.01 \pm 0.1 \mathrm{bc}$ & $1.33 \pm 0.15 \mathrm{c}$ & $0.36 \pm 0.02 \mathrm{c}$ & $6.1 \pm 0.9 \mathrm{c}$ & $1.5 \pm 0.02 \mathrm{bc}$ \\
\hline MS+MW & $18.06 \pm 0.6 \mathrm{ab}$ & $3.24 \pm 0.1 \mathrm{a}$ & $1.8 \pm 0.1 \mathrm{~b}$ & $0.4 \pm 0.02 \mathrm{bc}$ & $7.5 \pm 0.3 \mathrm{ab}$ & $1.7 \pm 0.02 \mathrm{~b}$ \\
\hline SS+NW & $16.2 \pm 0.65 \mathrm{c}$ & $2.9 \pm 0.1 \mathrm{c}$ & $1.04 \pm 0.04 \mathrm{~d}$ & $0.24 \pm 0.01 \mathrm{e}$ & $6.4 \pm 0.4 \mathrm{c}$ & $1.41 \pm 0.04 \mathrm{c}$ \\
\hline SS+MW & $17.1 \pm 1 \mathrm{bc}$ & $2.97 \pm 0.1 \mathrm{c}$ & $1.5 \pm 0.3 \mathrm{bc}$ & $0.3 \pm 0.01 \mathrm{~d}$ & $7.5 \pm 0.4 \mathrm{ab}$ & $1.66 \pm 0.02 \mathrm{~b}$ \\
\hline
\end{tabular}

Dissimilar letters within mean and between columns are significantly different at $\mathrm{p} \leq 0.05$ level of significance by applying FISHER's LSD Test.

water bath was used to heat the reacting mixture up to $95^{\circ} \mathrm{C}$ for $30 \mathrm{~min}$, followed by rapid cooling in an ice bath. The cooled mixture was centrifuged at $11,500 \times \mathrm{g}$ for 15 mins, which produced colored supernatant whose optical density was measured at $532 \mathrm{~nm}$. In addition, a correction was made for non-specific absorbance at $600 \mathrm{~nm}$. MDA concentration was expressed as nanomoles / gram fresh weight using extinction coefficient as $155 \mathrm{mM}^{-1} \mathrm{~cm}^{-1}$.

\section{Measuring $\mathrm{H}_{2} \mathrm{O}_{2}$}

To measure the hydrogen peroxide $\left(\mathrm{H}_{2} \mathrm{O}_{2}\right)$, a homogenate was prepared from $0.5 \mathrm{~g}$ leaf sample followed by the addition of $3 \mathrm{~mL}$ of $50 \mathrm{mM}$ potassiumphosphate buffer ( $\mathrm{pH} 6.5)$ at $4^{\circ} \mathrm{C}$. At 11,500xg speed and 15 min time, the homogenate was centrifuged, and $3 \mathrm{ml}$ supernatant was collected, which was then allowed for the reaction with $1 \mathrm{~mL}$ of $0.1 \%$ titanium tetrachloride in $20 \% \mathrm{H}_{2} \mathrm{SO}_{4}$. The mixture was centrifuged again at $11,500 \mathrm{xg}$ for $15 \mathrm{~min}$ and kept at room temperature for $10 \mathrm{~min}$. The absorbance was quantified at $410 \mathrm{~nm}$ to determine the concentration of $\mathrm{H}_{2} \mathrm{O}_{2}$ and expressed as nanomoles/gram fresh weight.

\section{Statistical Analysis}

Minitab statistical software vs. 17 was used to perform basic statistical analysis and an ANOVA test at $5 \% \quad(P \leq 0.05)$ level of significance. Mean differences were among the groups tested by Fisher's LSD test.

\section{Results}

\section{Growth Parameters}

Drought-induced stress retarded the plant height, internode distances and leaflet number. We observed that MWT had a statistically significant effect in plant height of Moringa biotype measured at 5 DAT to 30 DAT (Fig. 1) compared to the normal water treatment (NWT). Application of MWT to the drought stress seedlings significantly restored the plant growth compared to the seedlings treated with NWT alone. In addition, morphological components such as root, shoot, and fresh and dry leaf weight were found to be mostly influenced by the MS and SS drought levels under NWT irrigation and MWT (Table 1).
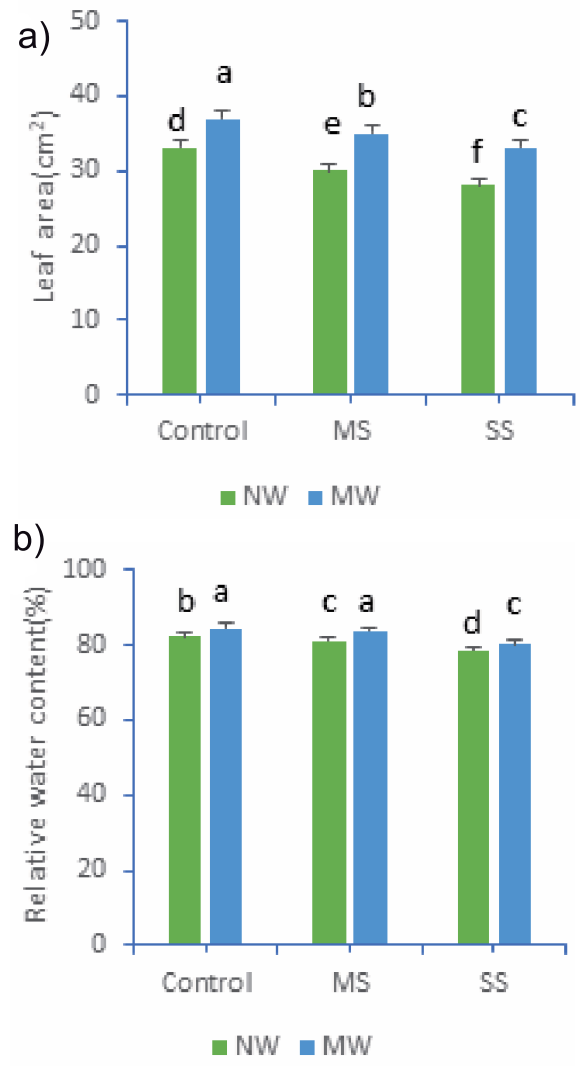

Fig. 2. Effects of magnetized water (MW) on the leaf area a), and relative water content $\mathrm{b}$ ) of the Moringa biotype under drought stress; dissimilar letters with mean are significantly different at $\mathrm{p} \leq 0.05$ level of significance by applying FISHER's LSD test. 
Table 2. Interaction effect between Moringa biotype vs. water on the chlorophyll content under different levels of drought stress $\left(\mathrm{mgg}^{-1} \mathrm{FW}\right)$.

\begin{tabular}{|c|c|c|c|c|}
\hline Treatments & Chl a & Chl b & Chl $(\mathrm{a}+\mathrm{b})$ & Carotenoids \\
\hline Control+NW & $1.3 \pm 0.03 \mathrm{c}$ & $0.78 \pm 0.02 \mathrm{~b}$ & $2.09 \pm 0.05 \mathrm{c}$ & $1.41 \pm 0.04 \mathrm{c}$ \\
\hline Control+MW & $1.54 \pm 0.03 \mathrm{a}$ & $0.87 \pm 0.01 \mathrm{a}$ & $2.41 \pm 0.04 \mathrm{a}$ & $1.63 \pm 0.03 \mathrm{a}$ \\
\hline MS+NW & $1.23 \pm 0.03 \mathrm{~d}$ & $0.67 \pm 0.04 \mathrm{c}$ & $1.9 \pm 0.01 \mathrm{e}$ & $1.38 \pm 0.01 \mathrm{~d}$ \\
\hline MS+MW & $1.41 \pm 0.03 \mathrm{~b}$ & $0.79 \pm 0.02 \mathrm{~b}$ & $2.2 \pm 0.01 \mathrm{~b}$ & $1.52 \pm 0.03 \mathrm{~b}$ \\
\hline SS+NW & $1.1 \pm 0.01 \mathrm{e}$ & $0.6 \pm 0.04 \mathrm{~d}$ & $1.7 \pm 0.05 \mathrm{f}$ & $1.23 \pm 0.03 \mathrm{e}$ \\
\hline SS+MW & $1.26 \pm 0.02 \mathrm{~cd}$ & $0.72 \pm 0.02 \mathrm{c}$ & $1.98 \pm 0.06 \mathrm{~d}$ & $1.44 \pm 0.01 \mathrm{c}$ \\
\hline
\end{tabular}

Dissimilar letters within mean and between columns are significantly different at $\mathrm{p} \leq 0.05$ level of significance by applying FISHER's LSD Test.
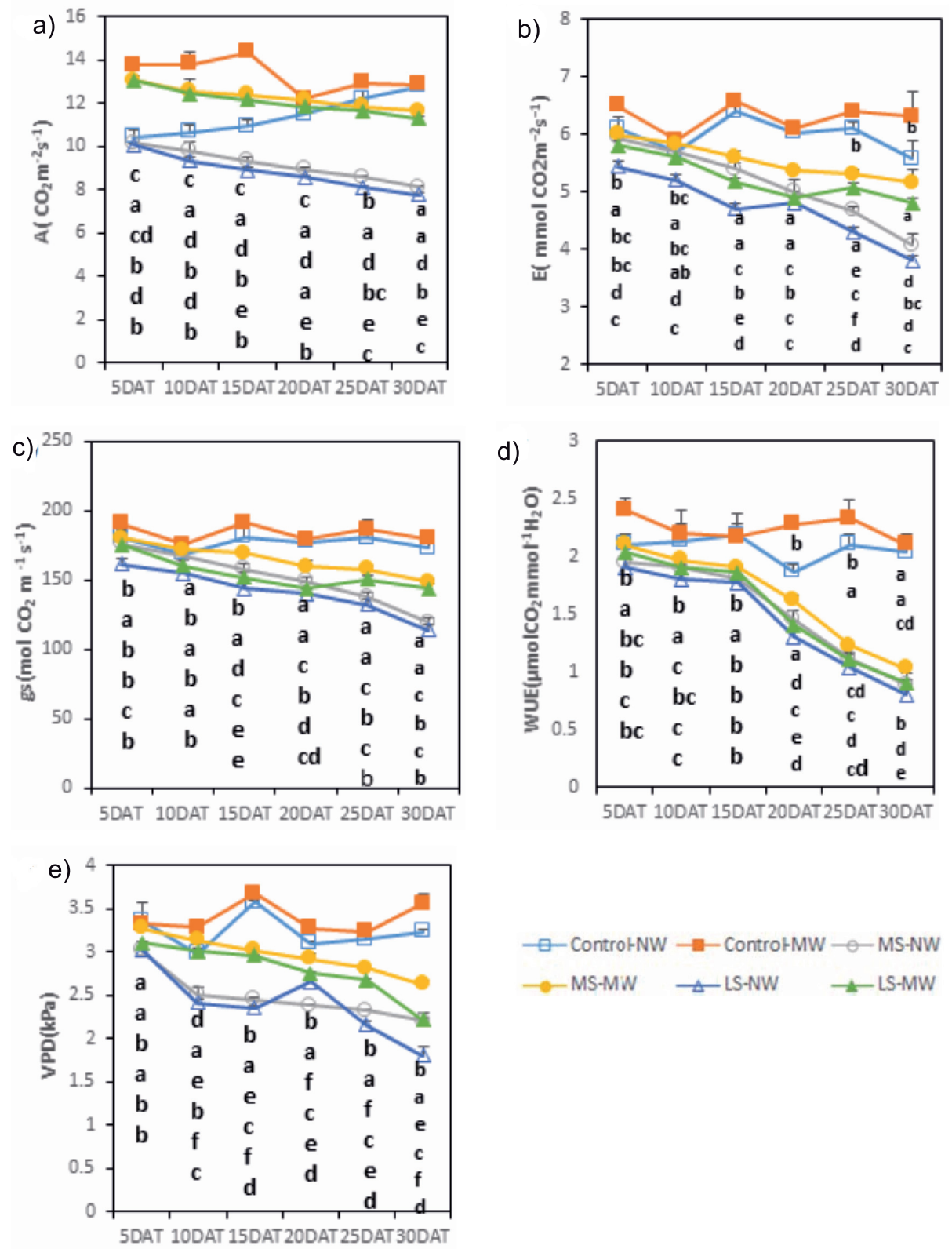

Fig. 3. Effect of magnetized water (MW) on the assimilation, A; a), transpiration, E; b), and stomatal conductance, gs; c), water use efficiency, WUE; d), and vapour pressure deficit, VPD; e) of the biotype under drought stress at 5DAT to 30DAT (days after treatment); vertical bars represent the standard deviation and different letters above and below the series denote statistically significant $(\mathrm{P} \leq 0.05)$ differences among treatments. 

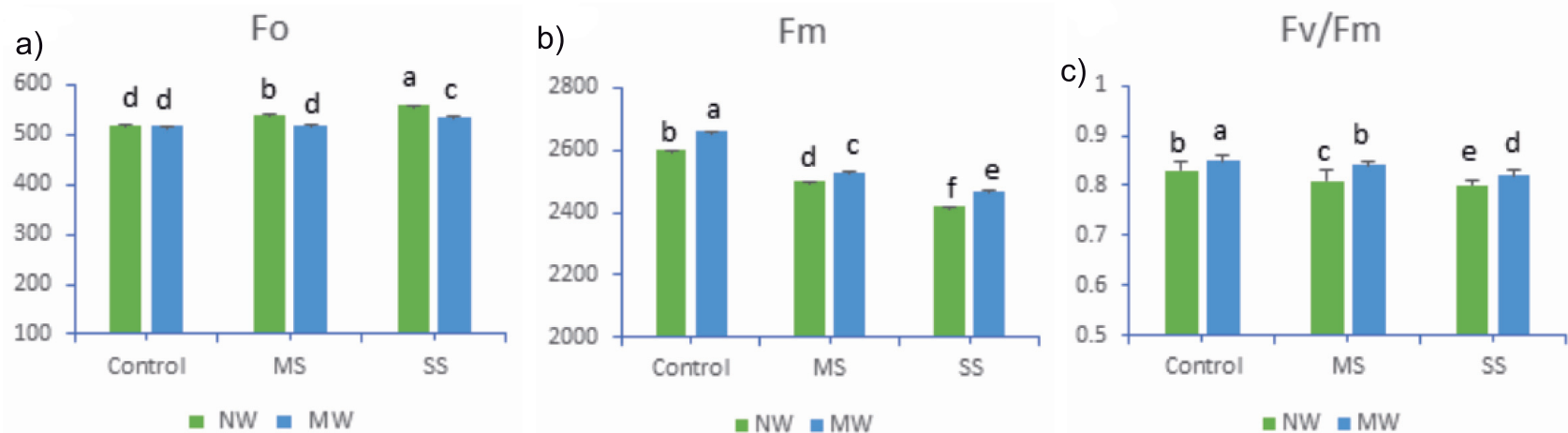

Fig. 4. Leaf chlorophyll fluorescence parameters of the Moringa biotype under drought stress with magnetized water; minimum chlorophyll fluorescence, $\mathrm{F}_{0}$; a), maximum chlorophyll fluorescence, $\mathrm{Fm}$; b) in the dark-adapted state, and maximum quantum efficiency of PSII, Fv/Fm; c); dissimilar letters with mean are significantly different at $\mathrm{p} \leq 0.05$ level of significance by applying FISHER's LSD test.

\section{Leaf Area (LA) and Relative Water Content (RWC)}

Drought stress significantly reduced the leaf area in Moringa biotype seedlings by $3 \%$ and $8 \%$ respectively, exposed to MS and SS level as compared to control under NWT (Fig. 2a). The Moringa biotype seedlings exposed to drought stress (MS, SS) showed $1 \%$ and $4 \%$ reductions in RWC compared to control seedlings under NWT (Fig. 2b).

Table 3. Interaction effect between Moringa biotype vs. water on ion content.

\begin{tabular}{|c|c|c|c|c|c|}
\hline Treatments & $\mathrm{Ca}^{2+}(\mathrm{mg} / \mathrm{L})$ & $\mathrm{Mg}^{2+}(\mathrm{mg} / \mathrm{L})$ & $\mathrm{Mn}^{2+}(\mathrm{mg} / \mathrm{L})$ & $\mathrm{P}^{5+}(\mathrm{mg} / \mathrm{L})$ & $\mathrm{Zn}^{2+}(\mathrm{mg} / \mathrm{L})$ \\
\hline \multicolumn{6}{|c|}{ Root } \\
\hline Control+NW & $27 \pm 1.8 \mathrm{c}$ & $12.4 \pm 1.17 \mathrm{~cd}$ & $0.18 \pm 0.02 \mathrm{a}$ & $14.3 \pm 0.57 \mathrm{~d}$ & $0.8 \pm 0.1 \mathrm{a}$ \\
\hline Control+MW & $31.9 \pm 1.9 \mathrm{a}$ & $15.4 \pm 1.2 \mathrm{a}$ & $0.18 \pm 0.01 \mathrm{a}$ & $24.3 \pm 0.57 \mathrm{a}$ & $0.84 \pm 0.06 \mathrm{a}$ \\
\hline $\mathrm{MS}+\mathrm{NW}$ & $25.7 \pm 1.8 \mathrm{~d}$ & $11.2 \pm 1.2 \mathrm{~d}$ & $0.17 \pm 0.01 \mathrm{~b}$ & $13 \pm 1 \mathrm{de}$ & $0.74 \pm 0.02 b$ \\
\hline MS+MW & $29.9 \pm 1.85 b$ & $14.3 \pm 1.2 \mathrm{~b}$ & $0.18 \pm 0.02 \mathrm{a}$ & $17.86 \pm 0.5 \mathrm{c}$ & $0.81 \pm 0.03 \mathrm{a}$ \\
\hline $\mathrm{SS}+\mathrm{NW}$ & $25.7 \pm 1.8 \mathrm{~d}$ & $9.6 \pm 1.2 \mathrm{e}$ & $0.14 \pm 0.025 \mathrm{~d}$ & $11.3 \pm 0.57 \mathrm{e}$ & $0.65 \pm 0.02 d$ \\
\hline $\mathrm{SS}+\mathrm{MW}$ & $29.9 \pm 1.85 \mathrm{~b}$ & $13.2 \pm 1.2 \mathrm{c}$ & $0.16 \pm 0.02 \mathrm{c}$ & $21 \pm 1 b$ & $0.72 \pm 0.01 \mathrm{c}$ \\
\hline \multicolumn{6}{|c|}{ Shoot } \\
\hline Control+NW & $60.4 \pm 2 d$ & $16.01 \pm 1.1 \mathrm{c}$ & $0.2 \pm 0.06 \mathrm{~cd}$ & $16.6 \pm 0.57 \mathrm{c}$ & $1.3 \pm 0.02 \mathrm{a}$ \\
\hline Control+MW & $79.5 \pm 2 \mathrm{a}$ & $27 \pm 1.14 \mathrm{a}$ & $0.5 \pm 0.06 \mathrm{a}$ & $27 \pm 1 \mathrm{a}$ & $0.8 \pm 0.03 \mathrm{e}$ \\
\hline $\mathrm{MS}+\mathrm{NW}$ & $56.3 \pm 2.05 \mathrm{e}$ & $12 \pm 1.14 \mathrm{~d}$ & $0.16 \pm 0.05 d$ & $15.66 \pm 0.5 \mathrm{~cd}$ & $1.12 \pm 0.03 b$ \\
\hline $\mathrm{MS}+\mathrm{MW}$ & $72.66 \pm 2.05 b$ & $25 \pm 1.14 \mathrm{ab}$ & $0.34 \pm 0.06 \mathrm{~b}$ & $26.33 \pm 1.5 \mathrm{a}$ & $0.87 \pm 0.02 \mathrm{~d}$ \\
\hline $\mathrm{SS}+\mathrm{NW}$ & $54.43 \pm 1.6 \mathrm{e}$ & $10.01 \pm 1.14 \mathrm{~d}$ & $0.15 \pm 0.05 d$ & $14 \pm 1 d$ & $1.0 \pm 0.005 \mathrm{c}$ \\
\hline $\mathrm{SS}+\mathrm{MW}$ & $68.3 \pm 2 c$ & $23.1 \pm 1.1 b$ & $0.28 \pm 0.06 \mathrm{bc}$ & $23.66 \pm 1.5 b$ & $0.8 \pm 0.02 \mathrm{e}$ \\
\hline \multicolumn{6}{|c|}{ Leaf } \\
\hline Control+NW & $74.5 \pm 2.008 \mathrm{~d}$ & $21 \pm 1.7 \mathrm{c}$ & $0.38 \pm 0.08 \mathrm{~b}$ & $22.3 \pm 0.57 b$ & $0.94 \pm 0.02 b$ \\
\hline Control+MW & $95.6 \pm 2.1 \mathrm{a}$ & $28.9 \pm 1.65 \mathrm{a}$ & $0.6 \pm 0.07 \mathrm{a}$ & $26 \pm 1 \mathrm{a}$ & $0.97 \pm 0.01 \mathrm{a}$ \\
\hline $\mathrm{MS}+\mathrm{NW}$ & $63.3 \pm 2.15 \mathrm{e}$ & $16.23 \pm 1.65 d$ & $0.34 \pm 0.09 \mathrm{c}$ & $21 \pm 1 b c$ & $0.91 \pm 0.01 \mathrm{c}$ \\
\hline MS+MW & $85.6 \pm 2.12 b$ & $26.03 \pm 1.7 \mathrm{ab}$ & $0.36 \pm 0.08 \mathrm{bc}$ & $27 \pm 1 \mathrm{a}$ & $0.96 \pm 0.01 \mathrm{a}$ \\
\hline $\mathrm{SS}+\mathrm{NW}$ & $60.13 \pm 2.15 \mathrm{e}$ & $12.1 \pm 1.7 \mathrm{e}$ & $0.3 \pm 0.08 \mathrm{~d}$ & $20 \pm 2 c$ & $0.81 \pm 0.01 d$ \\
\hline $\mathrm{SS}+\mathrm{MW}$ & $80.6 \pm 2.1 \mathrm{c}$ & $23.6 \pm 1.4 b c$ & $0.32 \pm 0.08 \mathrm{~cd}$ & $23.3 \pm 2 b$ & $0.9 \pm 0.01 \mathrm{c}$ \\
\hline
\end{tabular}

Dissimilar letters within mean and between columns are significantly different at $\mathrm{p} \leq 0.05$ level of significance by applying FISHER's LSD Test. 

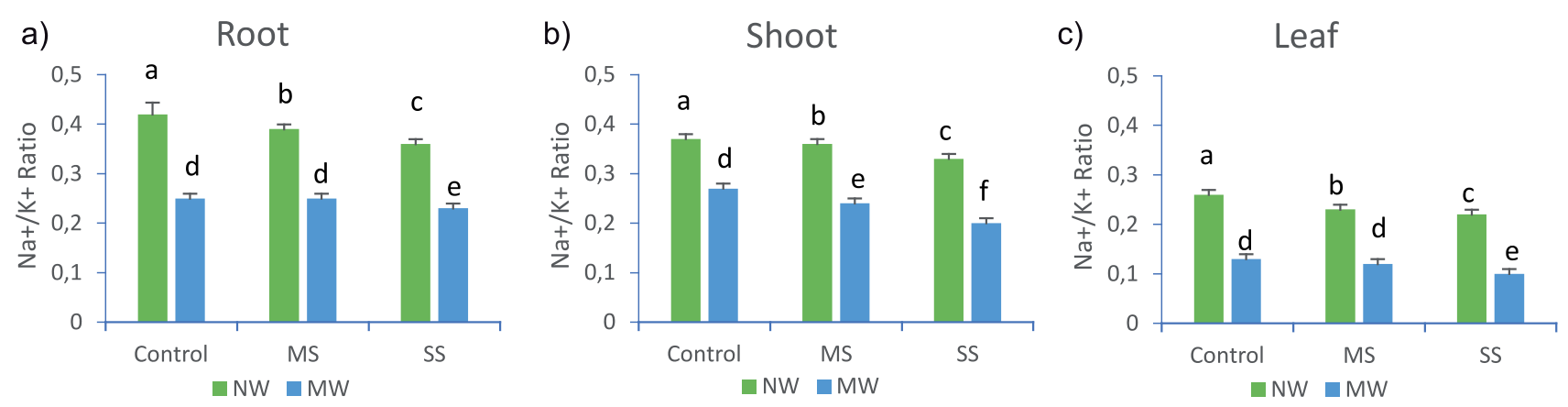

Fig. 5. Effects of magnetized water (MW) on the $\mathrm{Na}^{+} / \mathrm{K}^{+}$ratio of root (A), shoot (B), and leaf (C) of the Moringa biotype under drought stress; dissimilar letters with mean are significantly different at $\mathrm{p} \leq 0.05$ level of significance by applying FISHER's LSD test

\section{Leaf Gas Exchange}

Under $\quad 100 \% \quad$ FC (control level), assimilation (A), transpiration (E), and stomatal conductance (gs) were high in Moringa biotype at 5DAT to 30 DAT (Fig. 3a-c). At 30 DAT, drought stress caused a significant decrease in transpiration by $27 \% ; 44 \%$ exposed to MS and SS level under NWT. In addition, MWT seedlings showed a significantly higher transpiration rate than normal water-treated seedlings. Treating the Moringa biotype seedlings with drought considerably decreased the stomatal conductance compared with the control seedlings, whereas MW increased the stomatal conductance compared with the seedlings treated with drought alone. WUE and VPD were significantly affected by the different treatments. Different time of drought stress also was significantly affected by the MW (Fig. 3d,e).

\section{Chlorophyll Content}

The chlorophyll content $(\mathrm{Chl} \mathrm{a}, \mathrm{Chl} \mathrm{b}, \mathrm{Chl}(\mathrm{a}+\mathrm{b})$, carotenoids) increased under MWT (Table 2). Seedlings treated with MW and exposed to SS level showed $10 \%, 14 \%, 11 \%$, and $12 \%$ decreased in $\mathrm{Chl}$ a, Chl b, Chl $(a+b)$, and carotenoids content as compared to control seedlings. Chl a, Chl b, Chl $(\mathrm{a}+\mathrm{b})$, and carotenoids were decreased by $27 \%, 31 \%, 29 \%$, and
$22 \%$ respectively, and exposed to SS under normal water treatment (NWT) as compared to control seedlings (Table 2).

\section{Chlorophyll Fluorescence}

The minimum chlorophyll fluorescence (Fo) was significantly increased in drought treatment for Moringa biotype. A significant reduction of maximum chlorophyll fluorescence (Fm) was decreased in darkadapted leaves under MS and SS levels. $\mathrm{F}_{\mathrm{v}} / \mathrm{F}_{\mathrm{m}}$ ratio of the dark-adapted leaves was decreased in Moringa biotype seedlings by $2 \%, 4 \%$ exposed to MS, SS level under NWT (Fig. 4). The $F_{v} / F_{m}$ ratio significantly increased in the drought-stressed seedlings with MWT application.

\section{Determining Ion Content}

The ion content $\left(\mathrm{Ca}^{2+}, \mathrm{Mg}^{2+}, \mathrm{Mn}^{2+} \mathrm{P}^{5+}, \mathrm{Zn}^{2+}\right)$ in the roots, shoots and leaves decreased under drought stress (Table 3). The stress induced by drought decreased the $\mathrm{Ca}^{2+}, \mathrm{Mg}^{2+}, \mathrm{Mn}^{2+} \mathrm{P}^{5+}$, and $\mathrm{Zn}^{2+}$ in the shoots of Moringa biotype by $15 \%, 41 \%, 12 \%, 14 \%$, and $23 \%$ respectively, exposed to SS under normal water treatment as compared to control seedlings. However, MW improved the nutrient content in the Moringa biotype seedlings. The $\mathrm{Na}^{+} / \mathrm{K}^{+}$ratio was increased in the roots, shoot and

Table 4. Effects of drought stress on total phenolic (TP) and flavonoid content (TF) under magnetic water treatment (MWT) in the different irrigation regimes: $100 \%$ FC (Control), $50 \%$ FC (MS), 20\% (SS).

\begin{tabular}{|c|c|c|c|}
\hline Treatments & $\begin{array}{c}\text { Total phenolic Content (TP) } \\
(\mathrm{mg} / \text { gallic acid/g FW) }\end{array}$ & $\begin{array}{c}\text { Total Flavonoids Content (TF) } \\
(\mathrm{mg} / \text { catechin } / \mathrm{g} \mathrm{FW})\end{array}$ & $\begin{array}{c}\text { Proline content } \\
(\mu \mathrm{g} / \mathrm{g} \mathrm{FW})\end{array}$ \\
\hline Control+NW & $7.94 \pm 0.03 \mathrm{def}$ & $3.94 \pm 0.04 \mathrm{ef}$ & $824.3 \pm 2.52 \mathrm{~d}$ \\
\hline Control+MW & $8.07 \pm 0.01 \mathrm{de}$ & $4.04 \pm 0.03 \mathrm{e}$ & $818 \pm 2.65 \mathrm{e}$ \\
\hline MS+NW & $9.23 \pm 0.04 \mathrm{c}$ & $4.27 \pm 0.06 \mathrm{~d}$ & $905 \pm 5 \mathrm{c}$ \\
\hline MS+MW & $7.49 \pm 0.01 \mathrm{f}$ & $3.57 \pm 0.06 \mathrm{gh}$ & $1280.6 \pm 3.7 \mathrm{a}$ \\
\hline SS+NW & $12.28 \pm 0.05 \mathrm{a}$ & $5.21 \pm 0.21 \mathrm{a}$ & $1009 \pm 5.5 \mathrm{~b}$ \\
\hline SS+MW & $9.13 \pm 0.11 \mathrm{c}$ & $4.61 \pm 0.03 \mathrm{c}$ & $\mathrm{f}$ \\
\hline
\end{tabular}

Means within each column followed by the same letter are not significantly different at level $P \leq 0.05$ 
Table 5. Effects of drought stress on total phenolic (TP) and flavonoid content (TF) under magnetic water treatment (MWT) in the different irrigation regimes: $100 \% \mathrm{FC}$ (Control), $50 \% \mathrm{FC}$ (MS), 20\% (SS).

\begin{tabular}{|c|c|c|c|}
\hline Treatments & $\begin{array}{c}\text { MDA } \\
\text { Content } \\
\text { (nmol/g FW) }\end{array}$ & $\begin{array}{c}\mathrm{H}_{2} \mathrm{O}_{2} \\
\text { Content } \\
(\mathrm{nmol} / \mathrm{g} \mathrm{FW})\end{array}$ & $\begin{array}{c}\text { DPPH } \\
\text { (\%Inhibition) }\end{array}$ \\
\hline Control+NW & $21.48 \pm 0.19 \mathrm{~cd}$ & $5.81 \pm 0.01 \mathrm{c}$ & $49.7 \pm 0.06 \mathrm{ef}$ \\
\hline Control+MW & $22.43 \pm 0.5 \mathrm{c}$ & $5.75 \pm 0.01 \mathrm{c}$ & $50.68 \pm 0.07 \mathrm{e}$ \\
\hline MS+NW & $25.3 \pm 0.19 \mathrm{~b}$ & $7.37 \pm 0.06 \mathrm{~b}$ & $56.5 \pm 0.05 \mathrm{c}$ \\
\hline MS+MW & $19.59 \pm 0.12 \mathrm{e}$ & $6.49 \pm 0.09 \mathrm{~d}$ & $54.4 \pm 0.07 \mathrm{~d}$ \\
\hline SS+NW & $29.87 \pm 0.4 \mathrm{a}$ & $9.04 \pm 0.002 \mathrm{a}$ & $65.5 \pm 0.3 \mathrm{a}$ \\
\hline SS+MW & $25.14 \pm 0.19 \mathrm{~b}$ & $7.7 \pm 0.05 \mathrm{~b}$ & $62.64 \pm 1.07 \mathrm{~b}$ \\
\hline
\end{tabular}

Means within each column followed by the same letter are not significantly different at level $P \leq 0.05$

leaf in the drought-stressed seedlings and decreased with MW application (Fig. 5).

\section{Estimating Total Phenol Content (TPC)}

In the present study, we observed that magnetic water treatment (MWT) had a significant effect on TP in the Moringa biotype (Table 4). The Moringa biotype seedlings exposed to MS and SS levels exhibited 14\% and 35\% increased TP under NWT (Table 4).

\section{Estimating Total Flavonoid Content}

\section{(TFC)}

The total flavonoid contents were significantly increased under drought stress conditions. Under normal water treatment (NWT), the Moringa biotype seedlings exposed to MS and SS levels exhibited $8 \%$ and $24 \%$ increases in TF (Table 4).

\section{Proline Assay}

The proline content was significantly increased in Moringa biotype under drought stress (Table 4). Under drought stress (MS, SS), MWT resulted in decreased proline by $8 \%, 7 \%$ and $20 \%, 13 \%$ respectively.

\section{DPPH Assay}

DPPH was increased in Moringa biotype seedlings by $12 \%$ and $24 \%$ exposed to MS, SS level under NWT (Table 5). The Moringa biotype seedlings exposed to drought stress (MS, SS) showed 3\% and 4\% declines in DPPH under MWT.

\section{Lipid Peroxidation}

The Moringa biotype seedlings exposed to drought stress (MS, SS) showed $15 \%$ and $27 \%$ increases in
MDA content in the normal water treatment (NWT). A significant decrease in MDA content was observed in the Moringa biotype seedlings exposed to MW (Table 5).

$$
\mathrm{H}_{2} \mathrm{O}_{2} \text { Content }
$$

A significant increase in $\mathrm{H}_{2} \mathrm{O}_{2}$ content was observed under drought stress and NWT. The Moringa biotype seedlings exposed to drought stress (MS, SS) showed $12 \%$ and $14 \%$ decreases in $\mathrm{H}_{2} \mathrm{O}_{2}$ under MWT (Table 5).

\section{Discussion}

Drought stress affects the physiological and phonological characteristics of plants [36-37]. In our study, plant height, internode distances, and leaflet number were declined under MS and SS levels (Fig. 1), and the notable recovery was found under MWT during drought stress due to the improvement of cell division and cell expansion. MWT might have enhanced the photosynthetic reaction rate, which in turn increased LA, FW, and DW (Table 1). These results corresponded with the findings of Souza et al. (2006) [38], who claimed that DW of seedlings was highly increased under magnetic water treatment in comparison to control. In corn plants, MW reduced the adverse effects on the growth [39] caused by drought. Moringa biotype seedlings that underwent drought stress showed low RWC (Fig. 2), which proved that drought stress creates an osmotic stress condition and causes imbalance of water [37]. Magnetic water helped to restore the water loss by enhancing the RWC in the seedlings affected by drought stress.

In our study, we have found that MW increases the assimilation (A), transpiration rate (E), stomatal conductance (gs), WUE, and VPD in Moringa biotype during MS and SS levels of drought. Similar results were explained by Anand et al. 2012 [40] in Zea mays (Fig. 3). The chlorophyll a and photochemical quenching and non-photochemical quenching were improved by the MWT, which helped improve the photosynthetic reaction rate in Moringa biotype.

Fluorescence parameter $\mathrm{Fv} / \mathrm{Fm}$ was used to determine the stress in plants [41]. Fv/Fm was decreased in Moringa biotype, which is caused by harmful effects of drought (Fig. 4). The reduction of Fv/Fm and Fm could be due to structural obliteration of the PSII complex. Fv/Fm ratio, Fo and Fm were recovered by the MWT in Moringa biotype. Perhaps MWT helps to restore the photochemical efficiency of photosystem II in Moringa biotype. Chlorophyll fluorescence yield was found to be higher in soybean plants [42] under MWT, supported our result.

We observed that $\mathrm{Chl} a, \mathrm{Chl} b \mathrm{Chl}(\mathrm{a}+\mathrm{b})$ and carotenoids content declined under drought stress, and chlorophyll content increased in the leaves of Moringa 
biotype seedlings during MWT (Table 2). Previous studies showed similar results, where MW increased the chlorophyll content in soybean and maize leaves [43-46].

In our studies, we noticed that during drought stress conditions caused by water shortage and the amount of $\mathrm{Ca}^{2+}, \mathrm{Mg}^{2+}, \mathrm{Mn}^{2+}, \mathrm{P}^{5+}$, and $\mathrm{Zn}^{2+}$ was decreased (Table 3). Previous studies supported our result, where MW helps to increase the ion content [47]. The sodium ion concentration was found to be higher in the roots and shoots of the Moringa biotype (Fig. 5). $\mathrm{Na}^{+} / \mathrm{K}^{+}$ratio was increased due to the higher concentration of $\mathrm{Na}^{+} / \mathrm{K}^{+}$in Moringa biotype seedlings (Fig. 5). This may be due to the displacement of calcium ion by sodium ion $\left(\mathrm{Na}^{+}\right)$, causing the lower content of $\mathrm{Ca}^{2+}$. The similar result was found in rice seedlings under salt stress [48].

Phenolic and flavonoid content was affected under water deficit conditions [49-50]. Moringa biotype had higher phenolic compounds under drought stress environment (Table 4). The soluble carbohydrates accumulation in the plant cells were attributed to the phenolic compounds due to decreasing the transportation of soluble sugars [51-52]. The magnetic field rearranged the pyramid shape of water structure and it became the new hexagonal structure that can easily pass in cell membrane [24]. Possibly, magnetized water accelerates soluble sugar transportation in cell membranes by decreasing the accumulation of phenolic compounds under a drought environment. The proline content was increased in Moringa biotype under the different levels of drought stress. Increasing proline content in plants under drought is the sign of stress initiation [53] (Table 4). MW lowering the proline content in Moringa biotype may be due to the decrease of osmotic stress. The higher antioxidant capacity was found in Moringa biotype under drought stress, and it was minimized by the MWT (Table 5). It has been reported that magnetic field (MF) affects the antioxidant system in the plants [54] that supported our outcome. Malonaldehyde (MDA) and $\mathrm{H}_{2} \mathrm{O}_{2}$ content were significantly increased in the Moringa biotype under drought conditions (Table 5). MW helped lower the MDA and $\mathrm{H}_{2} \mathrm{O}_{2}$ contents under drought conditions as compared to NW-treated seedlings (Table 5).

\section{Conclusions}

In our study, drought stress markedly impaired growth, leaf gas exchange and chlorophyll content of Moringa biotype, and MW was effective in recovering the drought tolerance by maintaining the growth and physiology. Thus, we recommend that the application of MW under a water deficit environment that could be useful for mitigating drought stress.

\section{Abbreviations}

DPPH,1-diphenyl-2- picrylhydrazyl; DW, Dry weight; FC, Field capacity; FW, Fresh weight; $\mathbf{H}_{2} \mathbf{O}_{2}$, Hydrogen peroxide; LA, Leaf Area; MDA, Malondialdehyde; MS, Moderate drought stress; MW, Magnetized water; MWT, Magnetic water treatment; MF, Magnetic field; NWT, Normal water treatment; OD, Optical density; RWC, Relative water content; SS, Severe drought stress; TCA, Tricholoroacetic acid; TPC, Total phenolic content; TFC, Total flavonoid content; TBA, Thiobarbituric acid; VPD, Vapor pressure deficit; WUE, Water use efficiency; Fv/Fm, Maximum quantum efficiency; $\mathbf{F}_{\mathbf{0}}$ Minimum chlorophyll fluorescence; Fm, Maximum chlorophyll fluorescence

\section{Acknowledgements}

The authors are thankful to the Dean of Scientific Research (DSR), King Abdulaziz University, Saudi Arabia for providing financial support.

\section{Conflict of Interest}

The authors declare no conflict of interest.

\section{References}

1. SEHGAL A., SITA K., KUMAR J., KUMAR S., SINGH S., SIDDIQUE K.H.M., NAWAR H. Effects of Drought, Heat and Their Interaction on the Growth, Yield and Photosynthetic Function of Lentil (Lens culinaris Medikus) Genotypes Varying in Heat and Drought Sensitivity. Front. Plant Sci. 8, 1776, 2017.

2. LIPIEC J., DOUSSAN C., NOSALEWICZ A., KONDRACKA K. Effect of drought and heat stresses on plant growth and yield: a review. Intl. Agrophy. 27, 463, 2013.

3. HASSAN F.A.S., ALI E.F. Impact of different water regimes based on class - A pan on growth, yield and oil content of Coriandrum sativum L. plant. J. Saudi Soc. Agric. Sci., 13, 155, 2014.

4. AWASHTI R., KAUSHAL N., VADEZ V., TURNER N.C., BERGER J., SIDDIQUE K.H.M., NAYAR H. Individual and combined effects of transient drought and heat stress on carbon assimilation and seed filling in chickpea. Func. Plant Biol., 41, 1148, 2014.

5. BARNABAS B., JAGER K., FEHER A. The effect of drought and heat stress on reproductive processes in cereals. Plant Cell Environ., 31, 11, 2008.

6. TARDIEW F., SIMONNEAU T., MULLER B. The physiological basis of drought tolerance in crop plants: A scenario-dependent probabilistic approach. Ann. Rev. Plant Biol. 69, 733, 2018.

7. CHAI Q., GAN Y., ZHAO C., XU H.L., WASKOM R.M., NIU Y., SIDDIQUE K.H. Regulated deficit irrigation for crop production under drought stress. A review. Agron. Sustain. Dev. 36, 3, 2016. 
8. NAHAR K., HASANUAZZAMAN M., ALAM M.M., FUJITA M. Glutathione-induced drought stress tolerance in mung bean: coordinated roles of the antioxidant defense and methylglyoxal detoxification systems. AoB PLANTS 7, 1, 2015.

9. KHAN A., ANWAR Y., HASAN M.M., IQBAL A., ALI M., ALHARBY H.F., HAKEEM K.R., HASANUZZAMAN M. Attenuation of Drought Stress in Brassica Seedlings with Exogenous Application of $\mathrm{Ca}^{2+}$ and $\mathrm{H}_{2} \mathrm{O}_{2}$.Plants. 6, 20, 2017.

10. BLAMOWSKI Z.K., BOROWSKI E., PACZOS K. The effect of exogenous spermidine on cucumber plant (Cucumis Sativus L.) growth in drought stress. Acta Agribot. 54, 5, 2001.

11. GAO X.P., WANG X.F., LU Y.F., ZHANG L.Y., SHEN Y.Y., LIANG Z., ZHANG D.P. Jasmonic acid is involved in the water stress- induced betain accumulation in pear leaves. Plant Cell Environ. 47, 497, 2004.

12. AGARWAL S., SAIRAM R.K., SRIVASTAVA G.C., MEENA R.C. Changes in antioxidant enzymes activity and oxidative stress by abscisic and salicylic acid in wheat genotypes. Biol. Plant. 49, 541, 2005.

13. HASANUZZAMAN M., NAHAR K., HOSSAIN M.S., ANEE T.I., PARVEEN K., FUJITA M. Nitric oxide pretreatment enhances antioxidant defense and glyoxalase systems to confer PEG-induced oxidative stress in rapeseed. J. plant Inter. 12, 323, 2017.

14. HASAN M.M., ALHARBY H.F., HAJAR A.S., HAKEEM K.R., ALZAHRANI Y. Effects of magnetized water on phenolic compounds, lipid peroxidation and antioxidant activity of Moringa Species Under Drought Stress. J. Animal Plant Sci. 28, 803, 2018.

15. HASAN M.M., ALHARBY H.F., HAJAR AS., HAKEEM K.R. Leaf gas exchange, $\mathrm{Fv} / \mathrm{Fm}$ ratio, ion content and growth conditions of the two Moringa species under magnetic water treatment. Pak. J. Bot.49, 921, 2017.

16. CAI R., YANG H., HE J., ZHU W. The effects of magnetic fields on water molecular hydrogen bonds. J. Mol. Struct. 938, 15, 2009.

17. HASAN D., BRANSON D. Effectiveness of magnetic water treatment in suppressing calcium carbonate scale deposition. Ind. Eng. Chem. Process Design Devlop. 24, $588,1985$.

18. GEHR R., ZHAI Z.A., FINCH J.A., RAO S. Reduction of soluble mineral concentrations in $\mathrm{CaSO}_{4}$ saturated water using a magnetic field. Water Res. 29, 933, 1995.

19. COEY J., CASS S. Magnetic water treatment. J. Magnet. Magnetic Materials. 209, 71, 2000.

20. BOGATIN J., BONDARENKO N.P., GAK E.Z., Rokhinson, E.E., ANANYEV I.P. Magnetic treatment of irrigation water: Experimental results and application conditions. Environ. Sci.Technol. 33, 1280, 1999.

21. LIU X., ZHU H., MENG S., BI S., ZHANG Y., WANG H., SONG C., MA F. The effects of magnetic treatment of irrigation water on seedling growth, photosynthetic capacity and nutrient contents of Populus $\times$ euramericana 'Neva' under $\mathrm{NaCl}$ stress. Acta Physiol. Plantarum. 41, 1, 2019.

22. RENIA F.G., PASCUAL L.A., FUNDORA I.A. Influence of a stationary magnetic field on water relations in lettuce seeds. Part I: experimental results. Bioelectromagn. 22, 596, 2001.

23. MAHESHWARI B.L., GREWAL H.S. Magnetic treatment of irrigation water: Its effects on vegetable crop yield and water productivity. Agric. Water Manag. 96, 1229, 2009.
24. ALI Y., SAMANEH R., KAVAKEBIAN F. Applications of Magnetic Water Technology in Farming and Agriculture Development: A Review of Recent Advances. Cur. World Environ. 9, 695, 2014.

25. HASAN M.M., HAJAR A.S., ALHARBY H.F., HAKEEM K.R. The effect of magnetized water on the growth and physiological conditions of the Moringa species under drought stress. Polish J. Environ. Stud. 28, 1, 2019.

26. ROBIANSYAH I., RAMADAN A., AL-KORDY M.A., GHUSHHASH A.S., HAJAR A.S. Characterization of a new biotype Moringa of Saudi Arabia using RAPD and ISSR markers. Bul. Keb. Raya. 18, 99, 2015.

27. ROBIANSHAH I., GHUSHASH A.S., HAJAR A.S. Morphological characterization of a new biotype Moringa of Saudi Arabia. J. boil. Papua., 7, 47, 2015.

28. SELIM A.F.H., EL-NADY M.F. Physio-anatomical responses of drought stressed tomato plants to magnetic field. Acta Astro. 69, 387, 2011.

29. LICHTENTHALER H.K., WELLBURN A.R. Determination of Total Carotenoids and Chlorophylls a and $b$ of Leaf Extracts in Different Solvents. Biochem. Soc. Trans. 11, 591, 1983.

30. HUMPHRIES E.C. Mineral components and ash analysis. In: Modern Methods of Plant Analysis, Vol 1. Springer, Germany, 468, 1956.

31. VELIOGLU Y.S., MAZZA G., GAO L., OOMAH B.D. Antioxidant activity and total phenolics in selected fruits, vegetables, and grain products. J. Agric. Food Chem. 46, 4113, 1998.

32. ZHISHEN J., MENGCHENG T., JIANNING W. The determination of flavonoid contents in mulberry and their scavenging effects on superoxide radicals. Food Chem. 64, $555,1999$.

33. BATES L.S., WALDREN R.P., TEARE I.D. Rapid determination of proline for water-stress studies. Plant Soil. 39, 205, 1973.

34. AO C., LI A., ELZAAWELY A.A., XUAN T.D., TAWATA S. Evaluation of antioxidant and antibacterial activities of Ficus microcarpa L. extract. Food Cont. 19, 940, 2008.

35. HEALTH R.L., PACKER L. Photoperoxidation in isolated chloroplast. I. Kinetics and stoichiometry of fatty acid peroxidation. Archives Biochem. Biophys. 125, 189, 1968.

36. CANAVAR O., GOTZ K., ELLMER F., CHMIELEWSKI F.M., KAYNAK M.A. Determination of the relationship between water use efficiency, carbon isotope discrimination and proline in sunflower genotypes under drought stress. Aus. J. Crop Sci., 8, 232, 2014.

37. KHAN M.S.A., KARIM M.A., HAQUE M.M., ISLAM M.M., KARIM A.J.M.S., MIAN M.A.K. Influence of salt and water stress on growth and yield of soybean genotypes. Pertanika J. Trop. Agri. Sci. 39, 167, 2016.

38. SOUZA A.D., GARCIA D., SUEIRO L., LICEA L., PORRAS E. Pre-sowing magnetic treatment of tomato seeds: effects on the growth and yield of plants cultivated late in the season. Spanish Agric. Res., 3, 113, 2006.

39. JAVED N., ASHRAF M., AKRAM N., AL-QURAINY F. Alleviation of adverse effects of drought stress on growth and some potential physiological attributes in maize (Zea mays) by seed electromagnetic treatment. Photochem. Photobiol. 87, 1354, 2011.

40. ANAND A., NAGARANJAN S., VERMA A., JOSHI D., PATHAK P., BHARDWAJ J. Pre-treatment of seeds with static magnetic field ameliorates soil water stress in seedlings of maize (Zea mays L).Ind. J. Biochem. Biophys. 49, 63, 2012. 
41. MAXWELL K., JOHNSON G.N. Chlorophyll fluorescence a practical guide. J Exp Bot. 51, 659, 2000.

42. MAFFEI E.M. Magnetic field effects on plant growth, development, and evolution. Front. Plant Sci., 5, 1, 2014.

43. TURKER M., TEMIRCI C., BATTAL P., EREZ M.E. The effects of an artificial and static magnetic field on plant growth, chlorophyll and phytohormone levels in maize and sunflower plants. Phyton. Ann. Rei. Bot. 46, $271,2007$.

44. RADHAKRISHNAN R., KUMARI B.D.R. Influence of pulsed magnetic field on soybean (Glycine $\max \mathrm{L}$.) seed germination, seedling growth and soil microbial population. Ind. J. Biochem. Biophys. 50, 312, 2013.

45. KATARIA S., BAGHEL L., GURUPRASAD K.N. Effect of seed pretreatment by magnetic field on the sensitivity of maize seedlings to ambient ultraviolet radiation (280-400 nm).Int. J. Trop. Agric. 33, 1, 2015.

46. BAGHAL L., KATARIA S., GURUPRASAD K.N. Static magnetic field treatment of seeds improves carbon and nitrogen metabolism under salinity stress in soybean. Bioelectromag. 37, 455, 2016.

47. EITKEN A., TURAN M. Alternating magnetic field effects on yield and plant nutrient element composition of strawberry (Fragaria x ananassa cv. Camarosa). Acta Agric. Scandinavica Section B-Soil Plant Sci. 54, 135, 2004.

48. RAHMAN A., NAHAR K., Hasanuzzaman M,; Fujita M. Calcium Supplementation Improves $\mathrm{Na}^{+} / \mathrm{K}^{+}$Ratio, Antioxidant Defense and Glyoxalase Systems in SaltStressed Rice Seedlings. Front. Plant Sci. 7, 609, 2016.
49. SELMAR D., KLEINWACHTER M. Influencing the product quality by deliberately applying drought stress during the cultivation of medicinal plants. Indus. Crop. Prod. 42, 558, 2013.

50. QUAN N.T., ANH L.H., KHANG D.T., TUYEN P.T., TOAN N.P., MINH T.N., MINH L.T., BACH D.T., HA P.T., ELZAAWELY A.A., KHANH T.D., TRUNG K.H., XUAN T.D. Involvement of Secondary Metabolites in Response to Drought Stress of Rice (Oryza sativa L.). Agric. 6, 1, 2016.

51. JAAFAR H.Z.E., IBRAHIM M.H., KARIMI E. Phenolics and flavonoids compounds, phenylanine ammonia lyase and antioxidant activity responses to elevated $\mathrm{CO}_{2}$ in Labisia pumila (Myrisinaceae). Molecules 17, 6331, 2012.

52. GHARIBI S., TABATABAEI B.E.S., SAEIDI G., Goli S. Effect of Drought Stress on Total Phenolic, Lipid Peroxidation, and Antioxidant Activity of Achillea Species. Appl. Biochem. Bioethanol. 178, 796, 2016.

53. RAMPINO P., PATALEO S., GERARDI C., MITA G., PERROTTA C. Drought stress response in wheat: physiological and molecular analysis of resistant and sensitive genotypes. Plant Cell Env. 29, 2143, 2006.

54. CAKMAK T., CAKMAK Z.E., DUMLUPINAR R., TEKINAY T. Analysis of apoplastic and symplastic antioxidant system in shallot leaves: impacts of weak static electric and magnetic field. J. Plant Physiol . 169, 1066, 2012. 